\title{
HAMKA SEBAGAI SEJARAWAN: KAJIAN METODOLOGI SEJARAH TERHADAP KARYA HAMKA
}

\author{
Rahmi Nur Fitri \\ Universitas Islam Negeri (UIN) Sunan Kalijaga Yogyakarta, rabminurfi396@gmail.com
}

Diterima: 22 Januari 2020

Direvisi: 04 Juni 2020

Diterbitkan: 30 Juni 2020

\begin{abstract}
Hamka was a contemporary Indonesian Islamic figure who was involved in many fields. He wrote hundreds of books on various topics of study, philosophy, interpretation, history, customs and culture, literature, and others. When mentioning the name Hamka, then he was an ulama, while his roles in other fields are a little blurred. One of them is a depiction of the figure of Hamka as a historian. Some researchers recognize and acknowledge it as part of a historical researcher, some even study his historical philosophy, while for others give the view that he is not a historian. There are several characteristics and types of historians themselves, including professional historians, historians of other fields, and amateur historians or so-called community historians. The purpose of this paper is to uncover the methods employed by Hamka in writing his historical-themed works by looking at the intellectual socio-bistorical life. Through this study, it can be concluded that Hamka is included in the class of community historians because there is no formal academic bistory in his study. However, the various steps he went through in the writing process and his teaching experience are proof that Hamka is a bistorian.
\end{abstract}

Keywords: Hamka, History, Community Historian.

\begin{abstract}
Abstrak
Hamka adalah tokoh Islam Indonesia kontemporer yang menggeluti banyak bidang. Ia menulis ratusan buku dengan berbagai topik kajian, mulai dari filsafat, tafsir, sejarah, adat dan budaya, sastra, dan sebagainya. Jika menyebut nama Hamka, maka ia adalah seorang ulama, sedangkan peran-peran Hamka di bidang lainnya sedikit memburam. Salah satunya ialah penggambaran sosok Hamka sebagai seorang sejarawan. Sebagian peneliti mengenal dan mengakuinya sebagai bagian dari peneliti sejarah, bahkan beberapa mengkaji filsafat sejarahnya, sedangkan untuk sebagian lain memberikan pandangan bahwa ia bukanlah sejarawan. Terdapat beberapa karakteristik dan jenis dari sejarawan itu sendiri, di antaranya sejarawan profesional, sejarawan bidang lain, dan sejarawan amatir atau disebut sejarawan masyarakat. Tujuan dari tulisan ini adalah untuk mengungkap metode-metode yang dilakukan oleh Hamka dalam menuliskan karya-karyanya yang bertemakan sejarah dengan melihat sosio-historis intelektual kehidupannya. Melalui kajian ini dapat disimpulkan bahwa Hamka termasuk ke dalam golongan sejarawan masyarakat, karena tidak adanya riwayat akademiknya secara formal dalam kajian sejarah. Namun, berbagai langkah-langkah yang ia lalui dalam proses menulis dan pengalamannya mengajar adalah bukti bahwa Hamka adalah seorang sejarawan.
\end{abstract}

Kata Kunci: Hamka, Sejarah, Sejarawan Masyarakat. 


\section{PENDAHULUAN}

Puncak intelektualisme di Minangkabau berlangsung pada paruh pertama abad 20 . Kolonialisasi bangsa Barat dan kelahiran tokohtokoh pembaharu dari Timur Tengah telah melahirkan polemik baru di tengah-tengah dunia Islam. Kontestasi dan konfrontasi kelompok agama di Minangkabau ini kemudian memunculkan iklim intelektual yang menghasilkan ratusan karya tulis. ${ }^{1}$ Haji Abdul Karim Amrullah (Hamka) adalah salah satu buah dari pergolakan intelektual tersebut. Lahir dari keluarga religius yang terlibat langsung dalam pembaharuan di Minangkabau, telah membentuk karakteristiknya untuk menjadi seorang cendikiawan. $^{2}$

Tumbuh di lingkungan yang intelektual mengantarkan Hamka menjadi pribadi yang mencintai ilmu. Ia banyak menulis buku dengan berbagai topik seperti sejarah, filsafat, tafsir, teologi, sastra, dan lainnya. ${ }^{3}$ Setiap tema yang ia tuliskan selalu ia kaitkan dengan sejarah. Kecintaannya terhadap sejarah ia sampaikan di dalam kata pengantar beberapa buku karangannya.

Kontribusi yang besar sebagai seorang ulama di Indonesia, dan beberapa negara di Asia Tenggara, menjadikan Hamka lebih dikenal oleh masyarakat Indonesia sebagai seorang pendakwah dan pujangga. Namun, sedikit sekali literatur yang menyinggung ia sebagai seorang sejarawan. Salah satunya adalah topik yang mengkaji tentang filsafat sejarah Hamka oleh Fabian Fadhly Jambak. ${ }^{4}$ Beberapa peneliti lainnya, seperti

1 Apria Putra, "Ulama Dan Karya Tulis: Diskursus KeIslaman Di Minangkabau Awal Abad 20," Fuaduna: Jurnal Kajian Keagamaan Dan Kemasyarakatan 1, no. 2 (2017): 134 47, https://doi.org/http://dx.doi.org/10.30983/ fuaduna. v1i2.434.

2 Azyumardi Azra, The Origins Of Islamic Reformism In Southeast Asia (Honolulu: Allen \& Unwin and University of Hawai'i Press, 2004), 152.

${ }^{3}$ Khairudin Aljunied, "Reorienting Sufism: Hamka and Islamic Mysticism in the Malay World," Indonesia 101, no. 1 (2016): 67-84, https://doi.org/10.1353/ind.2016.0012.

${ }^{4}$ Fabian Fadhly Jambak, "Filsafat Sejarah Hamka: Refleksi Islam Dalam Perjalanan Sejarah," Jurnal
Khairudin Aljunied juga meneliti pemikiran Hamka seputar neo-sufisme. Ia menyebutkan bahwa dalam berbagai tulisannya seputar sufi, Hamka selalu memulai dengan perjalanan sejarah dari sufi atau tarekat itu sendiri. ${ }^{5}$

Meskipun sebagian peneliti menerima Hamka dan mengakuinya sebagai seorang sejarawan, tetapi tradisi intelektual di Indonesia tidak terlalu menerimanya sebagai seorang tokoh sejarawan. Hal ini diungkapkan oleh Nasir Tamara bahwa untuk tradisi di Eropa dan Arab sangat mengakui sejarawan seperti Hamka. Namun tradisi di Indonesia sama sekali berbeda, yang mana seorang sejarawan adalah mereka yang mengajar dan mengenyam pendidikan formal di bidang ini. ${ }^{6}$ Karya-karya berupa tulisan-tulisan sejarah yang terbilang cukup banyak dan dijadikan sebagai referensi, serta ketertarikannya yang sangat kuat terhadap sejarah adalah alasan untuk menyebut Hamka sebagai salah seorang sejarawan sekaligus tokoh sejarah di Indonesia. Selain itu, menganalisis tulisan-tulisan sejarahnya, menunjukkan bahwa metode yang digunakan Hamka sudah termasuk ke dalam langkah-langkah yang diwajibkan bagi seorang sejarawan, seperti heuristik, verifikasi, interpretasi, dan historiografi. Metode sejarah itu sendiri menurut Hasan Umar adalah tahapan-tahapan yang harus ditempuh oleh peneliti untuk mencapai hakikat sejarah, yang mana hasilnya disampaikan kepada pembaca dan para ahli. ${ }^{7}$

Mengutip istilah yang digunakan oleh Murni Djamal bahwa perjalanan Hamka sebagai salah satu sejarawan Indonesia "yang sampai

THEOLOGIA 28, no. 2 (February 20, 2018): 255-72, https://doi.org/10.21580/teo.2017.28.2.1877.

5 Khairudin Aljuneid, "In Defense of Guided Reason: Hamka and The Reconstruction of Southeast Asian Islam," History Religion 1, no. 1 (2017): 107-28.

6 Hal ini diungkapkan oleh Nasir Tamara yang disampaikan dalam Bedah Buku Adicerita Hamka di Islamic Centre, Masjid Universitas Ahmad Dahlan pada tanggal 28 Desember 2017.

${ }^{7}$ Basri, Metodologi Penelitian Sejarah: Pendektan, Teori Dan Praktik (Jakarta: Restu Agung, 2006), 34. 
sekarang tidak ditelaah di tingkat yang patut." Jika tolok ukur seorang sejarawan di Indonesia adalah seseorang yang mengajar di bidang sejarah, maka Hamka adalah yang termasuk di dalamnya. Hanya saja ia tidak memiliki pendidikan formal dalam bidang ini.

Kuntowijoyo sebagai seorang sejarawan Indonesia kemudian membuat klasifikasi sejarawan ke dalam beberapa kategori: pertama, sejarawan profesional adalah mereka yang berasal dari lulusan sejarah. ${ }^{9}$ Kedua, sejarawan dari disiplin lain adalah para ahli dari disiplin-disiplin ilmu selain sejarah yang menuliskan peristiwa-peristiwa penting di masa lalu dari bidang keilmuannya, maka jadilah tulisannya tersebut sebagai sebuah karya sejarah. Berdasarkan karya inilah ia kemudian bisa disebut sebagai sejarawan dari disiplin ilmu lain. Ketiga, yaitu sejarawan masyarakat atau bisa disebut juga dengan "sejarawan amatir." Para penulis sejarah yang masuk ke dalam golongan ini adalah mereka yang memiliki ketertarikan kepada sejarah dan berkeinginan untuk menuliskannya sehingga tidak akan hilang begitu saja. ${ }^{10}$

Hamka sendiri menyebutkan bahwa ia telah tertarik dengan sejarah sejak kanak-kanak di dalam beberapa buku karangannya. Pernyataan ini kemudian ia realisasikan dengan menulis berbagai tulisan yang bertemakan sejarah Islam, seperti Sejarah Umat Islam dan Ayabku. Minat dan perspektif Hamka yang kuat terhadap sejarah sedikit banyaknya dipengaruhi oleh latar belakang kehidupannya. Menurut Sartono Kartodirdjo, salah satu cara untuk mengetahui model intelektual seseorang adalah dengan memahami hubungan dan latar belakang sosial-kultural sipemikir guna memperkirakan faktor-faktor yang

8 Murni Djamal, Dr. H. Abdul Karim Amrullah: Pengarubnya Dalam Gerakan Pembaruan Islam Di Minangkabau Pada Awal Abad Ke-20 (Jakarta: INIS, 2002), 10.

${ }^{9}$ Kuntowijoyo, Pengantar Ilmu Sejarah (Yogyakarta: Tiara Wacana, 2013), 66.

${ }^{10}$ Kuntowijoyo, 68. mempengaruhinya. ${ }^{11}$ Adapun metode yang digunakan untuk menjabarkan sisi seorang sejarawanan Hamka adalah dengan model deskriptif-analitis melalui sosio-historis, guna menemukan lebih jauh proses perubahan dan pemahaman intelektualnya.

\section{LATAR BELAKANG KEHIDUPAN HAJI ABDUL MALIK KARIM AMRULLAH}

Hamka, yang bernama lengkap Haji Abdul Malik Karim Amrullah, lahir pada awal abad ke 20, tepatnya pada malam Senin tanggal 17 Februari 1908. ${ }^{12}$ Ia berasal dari salah satu keluarga ulama terpandang di Minangkabau. Hamka adalah putera pertama dari Haji Abdul Karim Amrullah dari pernikahan keduanya dengan Syafiah. $^{13}$ Ayahnya yang juga dikenal dengan sebutan Haji Rasul, merupakan tokoh pelopor dari gerakan "Kaum Mudo" di Minangkabau pada waktu itu, sedangkan keluarga ibunya adalah orang-orang terpandang dalam adat. ${ }^{14}$ Berasal dari keluarga yang memiliki pemahaman yang ketat dalam agama, serta baik dalam hal adat, dan juga lingkungan yang tengah dilanda oleh pembaharuan memengaruhi intelektualis seorang Hamka di kemudian hari.

Garis keturunan Hamka bersambung kepada salah seorang tokoh ulama Paderi di Ampat Angkat Agam. Nenek moyang Hamka

11 Sartono Kartodirdjo, Pendekatan Ilmu Sosial Dalam Metodologi Seiarah (Jakarta: Gramedia Pustaka Utama, 1992), 180-81.

${ }^{12}$ Hamka, Kenang-Kenangan Hidup, 1st ed. (Jakarta: Bulan Bintang, 1974), 9; Beberapa sumber menyebutkan bahwa Hamka lahir 16 Februari 1908. Lihat Najmuddin Ramly and Hery Sucipto, Ensiklopedi Tokoh Mubammadiyah (Jakarta: Best Media Utama, 2010), 176.

13 Sumber lain mengatakan bahwa ibu Hamka merupakan isteri ketiga ayahnya. Isteri pertamanya bernama Raihanah, kedua Hindun dan yang ketiga barulah ibu Hamka. Ibu Hamka Syafiah merupakan adik kandung dari isteri pertama Haji Rasul. Keduanya merupakan anak dari Haji Zakaria dan anak buah dari Datuk Rajo Endah suku Tanjung. Lihat Hamka, Ayabku: Riwayat Hidup DR. Haji Karim Amrullah Dan Perjuangan Kaum Agama Di Sumatera (Jakarta: Umminda, 1982), 63; James R. Rush, Adicerita Hamka: Visi Islam Sang Penulis Besar Untuk Indonesia Modern (Jakarta: Gramedia Pustaka Utama, 2017).

${ }^{14}$ Hamka, Kenang-Kenangan Hidup., 7. 
yang juga merupakan tokoh Paderi berpengaruh tersebut adalah Tuanku Pariaman yang bernama asli Abdullah Arif. Pernikahan Tuanku Pariaman dengan isterinya yang keempat di Sungai Batang Maninjau melahirkan seorang putera yang dikenal dengan nama Labai Putih Gigi dan seorang puteri bernama Siti Saerah. ${ }^{15}$ Putri Tuanku Pariaman, Siti Saerah, ia nikahkan dengan salah seorang muridnya yang bernama Abdullah Salaeh Tuanku Guguk Katur. Pasangan ini kemudian beroleh putera yang diberi nama Muhammad Amrullah yang merupakan kakek Hamka dari pihak ayah. Abdul Karim Amrullah atau Haji Rasul adalah putera ketiga Muhammad Amrullah dengan isteri ketiga yang bernama Andung Tarwasa di Batung Panjang. ${ }^{16}$

Hamka dilahirkan di Kampung Tengah yang termasuk ke dalam susunan nagari ${ }^{17}$ Sungai Batang yang terletak di pinggiran danau Maninjau sebelah selatan. Kampung Tengah berada di sebuah bukit di ujung pantai timur yang berbatasan langsung dengan pantai selatan, sekitar enam kilometer dari Maninjau. Digambarkan bahwa desa kelahiran Hamka adalah salah satu tempat terbaik untuk melihat pergantian cahaya matahari dari pantai barat di waktu pagi dan dari pantai timur di waktu sore menjelang senja. ${ }^{18}$

Hamka sebenarnya lahir di masa-masa munculnya pertentangan yang kuat antara Kaum Muda dan Kaum Tua di Minangkabau yang langsung dimotori oleh ayahnya sendiri. Gejolak idealisme antara Kaum Muda dan Kaum Tua

${ }^{15}$ Hamka, Ayabku: Riwayat Hidup DR. Haji Karim Amrullah Dan Perjuangan Kaum Agama Di Sumatera, 27-28; Rush, Adicerita Hamka: Visi Islam Sang Penulis Besar Untuke Indonesia Modern, 47.

16 Rush, Adicerita Hamka: Visi Islam Sang Penulis Besar Untuk Indonesia Modern, 47.

17 Nagari di Minangkabau bisa dikatakan hampir mirip dengan kecamatan, karena di dalam suatu nagari akan dibagi lagi ke dalam beberapa jorong (desa). Nagari diartikan sebagai suatu tempat atau daerah yang terdiri dari beberapa koto. Nagari secara formal berada di bawah pemerintahan para penghulu dengan balai adatnya. Lihat Idrus Hakim, Rangkaian Mustika Adat Basandi Syarak Minangkabau (Bandung: Rosdakarya, 1994), 114.

18 Leon Agusta, "Di Akhir Pementasan Yang Rampung," in Hamka Di Mata Hati Umat (Jakarta: Pustaka Sinar Harapan, 1996), 76. yang berakibat kepada terjadinya perdebatanperdebatan sengit tentang paham keagamaan juga menjadi salah satu faktor penting dalam pembentukan karakter Hamka di kemudian hari. ${ }^{19}$ Banyak opini yang menyebutkan bahwa gerakan Kaum Mudo ini adalah dampak idealis dari pergerakan Paderi yang terjadi beberapa tahun sebelumnya.

Hamka melalui masa kanak-kanaknya di Maninjau. Ia sama seperti anak laki-laki di Minangkabau lainnya yang harus tinggal di surau untuk belajar agama yang merupakan sebuah kebiasaan yang telah membudaya pada masa itu. ${ }^{20}$ Bahkan merupakan hal yang memalukan jika ada anak laki-laki yang tinggal di rumah. Hamka di waktu kecil sangat suka mengikuti kakeknya ${ }^{21}$ ke danau untuk memancing, berenang, bermain, serta mendengarkan cerita dan syair-syair. Hamka kecil bukanlah anak yang penurut. Ia digambarkan sebagai anak nakal yang pernah bolos sekolah selama berhari-hari, bermain silat, layangan, menonton adu sapi, pertandingan sepak bola hingga menonton ke bioskop. Kenakalan Hamka dapat dilihat dari cara ia menggambarkan ibunya sebagai ibu yang pemarah yang suka memukul, mencubit atau menjewernya. ${ }^{22}$ Sikap ibu Hamka yang diceritakannya itu juga pasti dikarenakan kenakalan-kenakalan yang dilakukan oleh Hamka. Ayahnya Haji Rasul bahkan menggelarinya dengan "Si Bujang Jauh" karena sikap nakal dan sering terlunta-lunta yang kemudian menjadikan ia suka berpergian dengan jalan kaki. ${ }^{23}$

19 Rusydi, Pribadi Dan Martabat Buya Prof. DR. Hamka (Jakarta: Pustaka Panjimas, 1983), 1.

20 Agusta, "Di Akhir Pementasan Yang Rampung," 78; Azyumardi Azra, Surau: Pendidikan Islam Tradisionalis Dalam Transisi Dan Modernisasi (Jakarta: Kencana, 2017), 76.

21 Kakek yang dimaksudkan di sini adalah dari pihak ibu. Sebagaimana diketahui kakek Hamka dari pihak ayah adalah Muhammad Amrullah yang meninggal setahun sebelum kelahira Hamka.

22 Rush, Adicerita Hamka: Visi Islam Sang Penulis Besar Untuk Indonesia Modern, 64.

23 Rusydi, Pribadi Dan Martabat Buya Prof. DR. Hamka, 10. 
Pada tahun 1916, salah satu murid Haji Rasul yang bernama Zainuddin Labay membuka sekolah Diniyyah Modern di Padang Panjang, jadilah Hamka sebagai salah satu murid di sana. Dua tahun setalah itu Haji Rasul mengubah Surau Jembatan Besi tempat ia mengajar dan menyebarkan pahamnya menjadi sebuah lembaga pendidikan resmi yang dinamai dengan Sumatera Thawalib. Hamka menghabiskan pagi hari untuk belajar di Diniyyah dan sore harinya di sekolah yang didirikan oleh ayahnya. ${ }^{24}$

Perhatian yang besar terhadap sejarah dimulai Hamka sewaktu ia bersekolah di Sumatera Thawalib dan Parabek. Sewaktu bersekolah di Sumatera Thawalib ia hanya menyukai dua mata pelajaran saja, yaitu syair-syair Arab dan sejarah. ${ }^{25}$ Kehadiran Balai Pustaka dan Pustaka Zainaro di Minangkabau sangat membantu Hamka untuk memenuhi keinginannya dalam membaca buku-buku sejarah berbahasa Melayu. Kepulangan Hamka dari Mekkah tahun 1928 menjadikan ia lebih memahami bahasa Arab dari pada sebelumnya, sehingga ia mampu membaca sejarah Islam tidak dari bahasa Melayu saja. Ia mengungkapkan bahwa ketertarikannya tidak pernah berubah, dan "buku-buku sejarah juga yang banyak menarik hati." $" 26$

Untuk pendidikan formal, Hamka hanya duduk di bangku Sekolah Rakyat kurang lebih dua tahun. ${ }^{27}$ Meski pendidikan formal Hamka hanya dua tahun, tapi pijakan yang kuat terhadap ilmuilmu agama yang diajarkan langsung oleh ayahnya menjadikan ia kelak menjadi seseorang yang mampu menyerap berbagai bidang keilmuan. Di samping itu rasa ingin tahu serta haus akan ilmu

${ }^{24}$ Rush, Adicerita Hamka: Visi Islam Sang Penulis Besar Untuk Indonesia Modern, 66.

${ }^{25} \mathrm{Hal}$ ini diungkapkan oleh Yunahar Ilyas yang disampaikan dalam Bedah Buku Adicerita Hamka di Islamic Centre, Masjid Universitas Ahmad Dahlan pada tanggal 28 Desember 2017.

26 Hamka, Sejarah Umat Islam, 4th ed. Jakarta: Bulan Bintang, 1976), 5.

27 Poeradisastra, "Dalam Karya Sastra Pun Berdakwah Dan Bekhorbah," in Hamka Di Mata Hati Umat (Jakarta: Pustaka Sinar Harapan, 1996), 121. merupakan satu bagian penting yang tidak bisa dipisahkan dari kemultitalentaan Hamka di kemudian hari. ${ }^{28}$ Hamka memulai bacaannya dari buku agama Islam, sejarah, sosial, politik, dan roman. Ketika berumur 13-14 tahun ia telah membaca buku-buku pemikiran Djamaluddin alAfghani, Muhammad Abduh, HOS Tjokroaminoto, KH. Mas Mansyur, dan lainlain. $^{29}$

Untuk persoalan adat Minangkabau, Hamka mempelajarinya dari Datuk Singo Mangkuto. ${ }^{30}$ Keahlian Hamka sebagai seorang orator ulung dimulai ketika ia bersekolah di Parabek. Di tempat ini ia sering melihat perlombaan mengadu merpati yang selalu didahului dengan kalimat yang indah-indah yang tersusun rapi. Ketertarikan Hamka akan pidatopidato tersebut menjadikan ia membaca serta menghafalkan berbagai pidato, syair, serta dongeng dari para tetua setempat. Salah seorang gurunya ialah mamak-nya ${ }^{31}$ sendiri yang bergelar Datuk Rajo Endah. Melalui pendalaman terhadap

28 Pendidikan otodidak Hamka dimulai saat ia sering mengunjungi perpustakaan Zainaro yang didirikan oleh Zainuddin Labai dengan Sinaro. Hamka menemukan berbagai buku-buku berbahasa Melayu, sastra-sastra Minangkabau generasi pertama, serta berbagai novel-novel terjemahan lainnya. Tampaknya salah satu faktor ia menyenangi sastra dimulai dari kegemarannya membaca berbagai buku sastra yang terdapat di perpustakaan ini. Ternyata hobi Hamka membaca buku sebanyak-banyaknya ini tidak disetujui begitu saja oleh ayahnya, Haji Rasul. Untuk mengalihkan perhatian, maka Haji Rasul mengirimnya ke sekolah agama di Parabek selama beberapa bulan. Lihat Hamka, Kenang-Kenangan Hidup, 83.

${ }^{29}$ Irfan Hamka, Ayah... (Jakarta: Republika, 2017), 230-31.

Rampung," 85.

30 Agusta, "Di Akhir Pementasan Yang

31 Di dalam susunan kekeluargaan di Minangkabau, mamak atau saudara laki-laki dari pihak ibu bertanggung jawab kepada kemenakan (anak dari saudara perempuan). Bahkan hal ini diungkapkan ke dalam pepatah petitih Minangkabau yang berbunyi "Anak dipangku, kamanakan dibimbiang" yang berarti seorang mamak tidak hanya bertanggung jawab kepada anaknya saja, melainkan juga bertanggung jawab kepada anak dari saudara perempuannya, yang disebut dengan kemenakan. 
syair-syair ini ia kemudian mendapatkan gelar adatnya, Datuk Indomo suku Tanjung. ${ }^{32}$

Rasa keingintahuan yang tinggi dalam diri Hamka kelak akan membawanya menuju titik yang cukup kontroversial. Kepandaiannya dalam membawakan berbagai kajian-kajian keislaman di depan publik telah membuat ia dikenal sebagai ulama yang memiliki banyak pendengar. Namun, ketertarikan Hamka yang besar terhadap sastra menimbulkan berbagai polemik mengenai dirinya. Pada tahun 1928 sebelum ia melangsungkan pernikahan dengan Siti Raham, Hamka telah menulis buku pertamanya yang bergenre melodrama Minangkabau yang berjudul Si Sabariyah. ${ }^{33}$ Di kemudian hari, bacaan-bacaan sastra yang sangat berpengaruh kepada tulisantulisan sastranya adalah sastra-sastra Arab, terutama karya Mustafa Lutfhi Al-Manfaluthi. Bahkan salah seorang yang kenal dengan Hamka, Datuk Panglimo Kayo mengungkapkan bahwa salah satu kunci kesuksesan yang dicapai oleh Hamka adalah berkat jiwa kesusastrawan dalam dirinya. Melalui bakat sastranya itulah Hamka mampu mencairkan suasana saat ia berpidato yaitu melalui bahasa-bahasa yang memikat. ${ }^{34}$ Selain itu gaya bahasa yang ia gunakan di dalam buku-bukunya menjadi lebih mudah untuk dipahami. Beberapa di antara karya sastra Hamka bahkan diangkat ke layar lebar untuk difilmkan, seperti Di Bawah Lindungan Ka'bah dan Tenggelamnya Kapal Van Der Wijk.

Sosok berpengaruh dalam mengembangkan potensi Hamka adalah kakak iparnya sendiri, Ahmad Rasjid Sutan Mansur, seperti ungkapan AR Sutan Mansur:

"Dari kecil dalam diri Abdul Malik Karim Amrullah memang sudah ada tanda-tanda akan menjadi orang besar. Kata dan fikirannya selalu didengar oleh teman-

32 Rush, Adicerita Hamka: Visi Islam Sang Penulis Besar Untuk. Indonesia Modern, 68; Hamka, Kenang-Kenangan Hidup, 82-83.

33 Rush, Adicerita Hamka: Visi Islam Sang Penulis Besar Untuk Indonesia Modern, 75; Hamka, Ayah..., 243. Rampung," 86. teman sebayanya, menjadikan ia selalu menonjol dalam pergaulan. Amat disayangkan ayah kami DR. H. Abdul Karim Amrullah tidaklah memahami hal itu, maka pada tahun 1925 saya berada di Pekalongan, Abdul Malik mengunjungi saya, maka mulai tahun itu saya mendidik dan mengarahkannya, sehingga sekarang telah sama-sama kita temui seorang Prof. Dr. Hamka." 35

Kisah perjalanan kehidupan Hamka menjadikan ia tertarik dengan hampir semua disiplin ilmu keislaman. Sejarah menjadi salah satu topik yang sangat ia senangi. Pada tulisan-tulisan sejarahnya ia memasukkan nilai-nilai filsafat di dalamnya. ${ }^{36}$ Selain itu dalam menuliskan karyakarya sejarah, ia lebih cenderung untuk melakukan periodesasi berdasarkan kepada waktu dari pada tempat. ${ }^{37}$ Hamka menghembuskan napas terakhirnya pada hari Jum'at tanggal 24 Juli 1981 di Jakarta karena sakit diabetes yang dideritanya. ${ }^{38}$

\section{HAMKA SEBAGAI SEJARAWAN: REFLEKSI DAN METODOLOGI}

Sejarah adalah satu cabang ilmu yang mengkaji persoalan-persoalan manusia di masa lampau. Sebagai sebuah ilmu barang tentu sejarah memiliki metode dan syarat-syarat tersendiri untuk mengakui sebuah tulisan atau karya hingga dapat dikategorikan sebagai sebuah karya sejarah. Orang yang meneliti dan menuliskan peristiwaperistiwa dari masa lampau dikenal sebagai sejarawan. Semua orang berkesempatan untuk menuliskan sejarah, sehingga semua orang pun bisa menjadi seorang sejarawan. Namun, muncul persoalan dan berbagai pertanyaan mengenai beberapa hal, seperti masihkah tulisan-tulisan itu bisa dikatakan sebagai sebuah sejarah yang mana jika ternyata sejarah memiliki metode tersendiri

35 Rusydi, Pribadi Dan Martabat Buya Prof. DR. Hamka, 21.

36 Jambak, "Filsafat Sejarah Hamka: Refleksi Islam Dalam Perjalanan Sejarah,” 257.

${ }^{37} \mathrm{Jambak}, 258$.

${ }^{38}$ Hamka, Ayah..., 279. 
dalam menentukan tulisan yang masuk ke dalam kajiannya. Untuk setiap orang yang memiliki kesempatan atau hobi dalam kajian kesejarahan, mungkinkah untuk digolongkan ke dalam sejarawan-sejarawan lainnya yang memang dididik untuk mengkaji sejarah secara utuh.

Banyak dari sejarawan yang berlatar belakang dari masyarakat yang menghasilkan karya bermutu, seperti Rusli Amran yang menulis mengenai Plakat Panjang di Sumatera Barat. Kuntowijoyo menyebutkan bahwa penelitiannya ini lebih dalam dari orang yang terdidik. Meski tetap ditemukan kekurangan pada tulisan-tulisan ini, di antaranya adalah tidak disertainya catatan kaki yang kemudian akan menyulitkan bagi peneliti yang ingin melacaknya. ${ }^{39}$

Berbeda dengan Kuntowijoyo yang mengategorikan sejarawan kepada tiga jenis, Mun'im Sirry di dalam bukunya yang berjudul Kemunculan Islam Dalam Kesarjanaan Revisionis hanya membagi sejarawan ke dalam dua kategori saja, yaitu: pertama, Sejarawan Tradisionalis, yaitu para sejarawan yang merekonstruksikan sejarah dengan tidak mempersoalkan keakurasian suatu data dan informasi dari sumber-sumber dan lebih berpegangan kepada penyampaian yang selaras dengan deskripsi yang diterima oleh umum. ${ }^{40}$ Tipe sejarawan ini adalah mereka yang tidak melakukan verfikasi kepada sumber-sumber yang ditemukan. Kedua, Sejarawan Revisionis, yaitu sejarawan kritis yang melihat data-data dan informasi sejarah melalui berbagai sumber dan sudut pandang. Sejarawan jenis ini sangat bertolak belakang dengan sejarawan tradisionalis, karena mereka mencoba merekonstruksikan sejarah melalui berbagai sumber-sumber dengan lebih detail. ${ }^{41}$ Sejarah jenis ini didasarkan kepada observasi atas fakta-fakta dan data yang bisa dianalisis.

Hamka mengungkapkan bahwa melalui sejarah ia bisa mengetahui berbagai hal-hal

\footnotetext{
${ }^{39}$ Kuntowijoyo, Pengantar Imu Sejarah, 68.

40 Mun'im Sirry, Kemunculan Islam Dalam Kesarjanaan Revisionis (Yogyakarta: Suka Press, 2017), 68.

${ }^{41}$ Sirry, 308.
}

penting. Ia sangat menyukai sejarah karena sejarah menginformasikan berbagai kemajuan peradaban-peradaban masa lampau. Hamka menekankan bahwa untuk mempelajari sejarah, seseorang harus mengembara dan melihat langsung kepada obyek yang diteliti. ${ }^{42}$ Mempelajari sejarah hanya dengan membaca dari buku-buku sejarah saja tidak akan cukup, karena menurut Hamka melihat langsung akan memberikan pemahaman yang mendalam, memperoleh penjelasan, petunjuk dan pengajaran. ${ }^{43}$ Pada tahun 1929 Hamka menyusun buku yang berjudul Pembela Islam, Sejarah Sayidina Abubakar Shiddiq, dan Ringkasan Tarikh Umat Islam. Tulisan sejarah pertama Hamka tentang sejarah Islam di Indonesia adalah mengenai Sumatera Thawalib dan gerakan reformis di Minangkabau yang dimotori oleh ayahnya, Haji Rasul. Hamka menuangkan gerakan ini ke dalam bentuk tulisan pada awal 1930-an berkat kesadarannya akan pentingnya pergerakan itu sebagai sebuah sejarah. ${ }^{44}$

Hamka sangat menyukai berkunjung ke berbagai tempat. Apalagi setelah menjadi seorang muballigh, ${ }^{45}$ intensitas berkunjungnya semakin bertambah. Melalui perjalanan ini ia memiliki

42 Landasan cara berfikir seperti ini Hamka dapatkan melalui ayat al-Qur'an surat Ali-Imran ayat 137: "Sesungguhnya beberapa contoh telah lalu sebelum kamu. Maka mengembaralah kamu di bumi, lalu tengoklah bagaimana akibat orang-orang yang mendustakan agama." Hamka, Tafsir Al-Azhar, 4th ed. (Jakarta: Pustaka Panjimas, 1984), 94.

${ }^{43}$ Hamka, Tafsir Al-Az̧har.

${ }^{44}$ Di kemudian hari Hamka membahas persoalan ini berkali-kali di dalam berbagai tulisannya. Melalui artikelartikel mengenai gerakan reformis ayahnya itulah awal Hamka menemukan jati dirinya sebagai seorang jurnalis. Dalam berbagai tulisan-tulisannya Hamka pernah memakai beberapa nama pena dan nama Hamka yang kemudian lebih terkenal. Lihat Rush, Adicerita Hamka: Visi Islam Sang Penulis Besar Untuk Indonesia Modern, 74.

45 Muballigh berasal dari bahasa Arab tabligh: balagha-yuballighu-tablighan yang memiliki arti menyampaikan seruan. Arti kata tabligh lebih sempit jika dibandingkan dengan dakwah, sedangkan muballigh adalah orang yang menyampaikan seruan. Hamka mengungkapkan bahwa tabligh adalah tiang terpenting dalam agama Islam yang harus diemban oleh seorang muballigh. Lihat Hamka, Prinsip Dan Kebijakan Dakwah Islam (Jakarta: Pustaka Panjimas, 1984), 2. 
kebiasaan untuk mencari tahu sejarah setempat, seperti yang ia pahami bahwa untuk mempelajari sejarah itu akan lebih baik jika melihat secara langsung kepada sumber dari obyek yang diteliti. Ia kemudian berkesempatan untuk bertanya kepada orang-orang tua dan orang terkemuka di daerah yang ia kunjungi mengenai sejarah-sejarah lokal setempat. Bahkan Hamka mengisahkan di dalam perjalanannya itu para sultan memberikan izin kepadanya untuk melihat dan meneliti arsipasrip sejarah yang disimpan dan masih berbentuk naskah. ${ }^{46}$

Sumber-sumber penulisan Hamka mengenai sejarah Islam di Indonesia tidak hanya berasal dari tulisan-tulisan pengarang lokal saja, ia juga banyak membaca tulisan-tulisan dari peneliti Belanda. Hamka melihat bahwa buku-buku sejarah Islam Indonesia yang dikarang oleh para pengarang Islam periode awal, seperti Hikayat Raja-raja Pasai oleh Syaikh Nuruddin Raniri tidak bisa melepaskan diri dari menuliskan dongengdongeng. ${ }^{47}$ Apresiasi Hamka terhadap penelitian yang dilakukan oleh orientalis sangat besar, meskipun ia menyadari bahwa tulisan-tulisan mereka memiliki "maksud tersembunyi" seperti kepentingan kolonial dan zending. Untuk sumbersumber yang berasal dari pihak kolonial, Hamka menjelaskan tulisan-tulisan mereka sangat mendukung untuk penelitian mengenai sejarah Islam di Indonesia, tapi Hamka menegaskan bahwa sebagai seorang Indonesia haruslah mampu untuk "meninggalkan kesan perasaannya sendiri (kepentingan kolonial) dan pendirian hidupnya serta maksud mereka yang tersembunyi." Ia menegaskan pentingnya untuk menghindari subyektifitas dalam meneliti sebuah peristiwa.

Sikap yang ditunjukkan oleh Hamka kepada sumber-sumber yang berasal dari karyakarya ilmuwan orientalis maupun peneliti Belanda adalah sikap kehati-hatian. Sikap ini dilatarbelakangi oleh dua hal: pertama, di dalam bidang

${ }^{46}$ Hamka, Sejarah Umat Islam, 1976, 9.
${ }^{47}$ Hamka, 7. sejarah ia melihat terdapat kesalahan fakta dari data yang sesungguhnya. Faktor inilah yang mungkin menjadikan Hamka meneliti dan merekontruksi ulang berbagai peristiwa sejarah seperti gerakan Paderi. Kedua, dalam bidang keagamaan Hamka melihat bahwa terdapat maksud terselubung yang bertujuan untuk mendiskreditkan Islam di dalam karya orientalis awal. ${ }^{48}$

Tujuan penulisan Hamka mengenai sejarah Islam di Indonesia dengan mengambil sumber-sumber kolonial adalah untuk menemukan "Sejarah Bangsa Indonesia" dengan cara memisahkannya dari "Sejarah Kolonial." Sejarah kolonial merupakan sejarah bangsabangsa asing di Indonesia yang ditinjau dan dituturkan menurut pengertian dan kepentingan dari bangsa-bangsa asing itu sendiri. Pada umumnya sejarah seperti ini menjadi kebanggaan bagi bangsa-bangsa yang pernah menjadi penjajah. $^{49}$ Meski perhatian dan cara yang dilakukan oleh Hamka untuk mendapatkan berbagai data-data sejarah sudah hampir melalui penelitian dengan menggunakan metode sejarah, namun ia tetaplah seorang "sejarawan masyarakat" yang tidak mempelajari metode penelitian sejarah secara mendalam.

Penelusuran Hamka terhadap sumbersumber yang dijadikan sebagai rujukan untuk menuliskan sejarah tidak luput dari kritik-historis yang mendalam. Salah satu perbandingan, penelusuran dan kritik yang dilancarkan Hamka adalah terhadap buku Tuanku Rao karya Ir. Mangaradja Onggang Parlindungan. Ia mengkritik buku ini secara keseluruhan dan dengan tegas mengatakaan bahwa ini adalah suatu kebohongan..$^{50}$ Aturan untuk merekonstruksikan

48 Samsul Nizar, Memperbincangkan Dinamika Intelektual Dan Pemikiran Hamka Tentang Pendidikan Islam (Jakarta: Kencana, 2008), 22.

49 Soedjatmoko, ed., Historiografi Indonesia: Sebuah Pengantar (Jakarta: Gramedia Pustaka Utama, 1995), 7.

50 Untuk menyanggah buku Parlindungan ini Hamka melakukan perjalanan ke museum-museum seperti Istana Alhambra dan tempat-tempat yang menyimpan berbagai arsip-arsip kesejarahan yang masuk ke dalam 
sejarah agar bisa dijadikan sandaran dan acuan haruslah melalui kritik-historis. Hal ini bertujuan untuk melihat lolos atau tidaknya pada ujian yang paling dasar, yaitu sumber-sumber sejarah yang digunakan. $^{51}$ Hal-hal inilah yag kemudian dipraktekan oleh Hamka untuk menuliskan bukubukunya tentang sejarah. Ketekunan Hamka dalam mengkaji sejarah menjadikan ia mampu menghidupkan masa lalu yang terlupakan serta menemukan pesan-pesan moral sejarah yang terkandung di dalamnya. ${ }^{52}$

Pengalaman Hamka tidak hanya berhenti dengan menuliskan sejarah, ia pernah mengajar sejarah Islam sejak tahun 1929 di Sekolah Muballigh (Tabligh School) yang didirikannya. Pada tahun 1951-1963 Hamka mengampu mata kuliah Sejarah Islam di Indonesia di Perguruan Tinggi Islam Jakarta (yang kemudian menjadi Universitas Islam Jakarta). Hamka juga mengisahkan bahwa setelah ia diangkat menjadi dosen di Perguruan Tinggi Agama Islam Negeri di Yogyakarta dari tahun 1954 sampai 1959, ia tetap bertanggung jawab untuk mata kuliah Sejarah Islam di Indonesia sama seperti saat ia mengajar di Perguruan Tinggi Islam di Jakarta. ${ }^{53}$ Setelah diangkat menjadi pengajar di perguruan tinggi, ia banyak diundang untuk mengikuti seminar-seminar sejarah Islam di Indonesia.

Berdasarkan kepada penjelasan di atas, maka tampaklah bahwa sosok Hamka selama ini

tulisan Parlindungan di dalam bukunya Tuanku Rao. Bahkan Hamka menekankan bahwa ia telah berulang kali ke museum tersebut dan tidak menemukan apa yang disebutkan di dalam buku Tuanku Rao. Hamka juga menyatakan ada beberapa kali ia tidak jadi bertanya karena takut akan mendapat malu saja. Kalimatnya ini bahkan mengandung sindiran kepada Parlindungan "Mulanya ada niat saya berkorespondensi kesana. Akhirnya niat itu saya urungkan. Takut dapat malu! Karena besar kemungkinan barang itu tidak ada! Entah kalau sepeninggal saya dia "ada" kembali. Mana tahu!" Tampaklah bahwa untuk memberikan sanggahan dan kesimpulan yang tegas Hamka langsung mencari ke sumber asalnya atau yang disebut dengan beuristik dalam kajian sejarah. Revisionis, 4.

51 Sirry, Kemunculan Islam Dalam Kesarjanaan

52 John L. Esposito, Ensiklopedi Oxford: Dunia Islam Modern, 2nd ed. (Bandung: Mizan, 2001), 147.

${ }^{53}$ Hamka, Sejarah Umat Islam, 1976, 5. sama sekali tidak ditonjolkan sebagai seorang sejarawan, meskipun karya-karya sejarahnya sangat banyak juga pengalamannya sebagai tenaga pengajar bidang sejarah. Penyebab kemunculan berbagai pandangan dan pendapat yang mengatakan tidak dikenalnya Hamka sebagai seorang sejarawan bisa jadi disebabkan oleh karyanya yang monumental, yaitu Tafsir al-Azhar. Melalui karyanya ini ia lebih dikenal sebagai seorang ulama. Alasan inilah yang menjadi faktor utama penyebab sisi ke-sejarawan Hamka menjadi terlupakan.

\section{KARYA-KARYA DALAM BIDANG SEJARAH}

Hamka adalah seorang pemikir bebas yang memiliki banyak karya. Ia memiliki lebih dari seratus buku dalam berbagai bidang, di antaranya: sejarah dan biografi, adat Minangkabau, politik, doktrin Islam, sastra, etika tasawuf dan tafsir. ${ }^{54}$ Hamka memiliki pandangan hidup bahwa seseorang itu harus berpikir bebas. Pandangan hidup seperti ini menjadikan ia ingin terus mencari ilmu dan tidak mau berhenti sebelum bertemu dengan hakikat dari ilmu itu. Menurutnya taraf kemajuan fikiran manusia itu bersangkutan pula dengan kecerdasan pribadi seseorang. ${ }^{55}$ Bermodalkan dengan prinsip hidup berfikir bebas mengantarkan Hamka untuk memiliki karya dalam berbagai bidang. Karyakarya Hamka yang termasuk ke dalam kajian sejarah adalah sebagai berikut:

\section{Sejarah Umat Islam}

Buku Sejarah Umat Islam ini dapat dikatakan sebagai karya besar Hamka dalam bidang sejarah. Buku ini berjumlah sebanyak empat jilid dengan jilid 1 ditebitkan tahun 1950, jilid 2 tahun 1952, jilid 3 1960, dan jilid terakhir diterbitkan tahun 1961. Karya ini mulai ia susun pada tahun 1939 dengan niat pada waktu itu ingin

\footnotetext{
${ }^{54}$ Esposito, Ensiklopedi Oxford: Dunia Islam Modern,

${ }_{55}$ Hamka, Pandangan Hidup Muslim (Jakarta: Bulan
} 147. Bintang, 1992), 72. 
"menerbitkan buah tangan yang agak besar." Buku yang menguraikan sejarah-sejarah umat Islam ini pada awalnya akan diterbitkan pada tahun 1941, tetapi karena melonjaknya harga kertas pasca perang menjadikan penerbitannya harus tertunda. Sepuluh tahun setelah itu buku ini baru bisa diterbitkan untuk pertama kalinya. Buku Sejarah Umat Islam ini kemudian diterbitkan lagi ke dalam edisi Malaysia pertama kali pada tahun 1965.

\section{Sejarah Islam di Sumatera}

Buku ini diterbitkan pertama kali pada pertengahan tahun 1945 di Medan oleh Pustaka Nasional. Cetakan keduanya diterbitkan pada tahun 1950. Pembahasannya mencakup Islam masuk Sumatera di Minangkabau, Palembang, dan juga di dalamnya dipaparkan peristiwaperistiwa sesudah Indonesia merdeka.

\section{Dari Pembendaharaan Lama}

Penyusunan buku ini telah dimulai oleh Hamka dari tahun 1955 yang dimuat berturutturut dalam "Mingguan Abadi" yang terbit di Jakarta. Buku ini diterbitkan pertama kali di Jakarta pada tahun 1963 oleh Pustaka Panjimas. Sedangkan untuk terbitan keduanya adalah tahun 1982. Dinamakan oleh Hamka buku ini dengan Dari Pembendaharaan Lama bukan tanpa alasan. Ia menyebutkan bahwa sumber-sumber dari penyusunan buku ini berasal dari simpanan pembendaharaan lama, atau yang disebutnya dengan buku pusaka peninggalan nenek moyang. Itulah alasan penamaan pada buku ini. Buku ini membahas mengenai sejarah Islam di tanah air. Penjelasan buku ini dimulai dengan "Pengembara Arab yang Pertama ke Indonesia" dan terus berlanjut kepada perjuangan-perjuangan yang terjadi di Indonesia pada masa kolonial.

\section{Pembela Islam: Sejarah Sayyidina Abu Bakar Shiddiq dan Ringkasan Tarikh Umat Islam}

Kedua buku sejarah ini adalah buku sejarah pertama yang disusun oleh Hamka ketika

56 Kalimat ini tertulis pada Pendahuluan jilid pertama dari buku ini. Lihat Hamka, Sejarah Umat Islam, 1st ed. (Jakarta: Bulan Bintang, 1975), 7. ia masih berada di Padang Panjang. Buku ini ia tulis pada saat berumur 22 tahun dan diterbitkan oleh Pustaka Nasional di Medan. Buku ini tidak banyak yang bisa diketahui, sebagaimana karya Hamka yang lainnya yang sudah sangat sulit untuk dikumpulkan. Hamka sendiri bahkan tidak mengarsipkan karya-karyanya, karena ia selalu meminjamkan buku-bukunya kepada orang-orang terdekat.

\section{Sejarah Perkembangan Pemurnian Ajaran Islam di Indonesia}

Pada awalnya ini adalah pidato yang disampaikan oleh Hamka di Universitas al Azhar di Kairo, Mesir. Diucapkan pada saat ia akan menerima gelar doktor honoris causa dari Universitas al Azhar pada tanggal 21 Januari 1958 di gedung Asy-Syubhan al Muslimun. Judul pidato yang disampaikan oleh Hamka tidak sama dengan judul buku ini, pidatonya berjudul "Pengaruh Ajaran dan Pikiran al Ustadz al Imam Syeikh Muhammad 'Abduh di Indonesia." Pada tahun 1961 penerbit Tintamas Djakarta meminta izin untuk menerbitkan pidato Hamka ini menjadi sebuah buku.

\section{Perkembangan Kebathinan di Indonesia}

Buku ini memuat uraian dan tinjauan tentang sejarah pertumbuhan dan perkembangan kebatinan di Indonesia, khususnya di tanah Jawa. Beberapa uraian yang dibahas di dalam buku ini adalah asal mulu tumbuhnya gerakan kebatinan, sebab-sebab timbulnya kebatinan, kebatinan ditinjau dalam sejarah, dan lainnya. Buku ini diterbitkan pertama kali pada tahun 1971 oleh penerbit Bulan Bintang.

\section{Ayahku: Riwayat Hidup DR. Haji Karim Amrullah dan Perjuangan Kaum Agama di Sumatera}

Karya ini adalah biografi Haji Rasul serta pengaruhnya di Minangkabau pada masa itu. Pertama kali diterbitkan pada tahun 1982. Tulisan ini memaparkan berbagai polemik keagamaan yang terjadi di Minangkabau. Perseteruan antara Kaum Mudo dan Kaum Tuo, serta awal mula masuknya Muhammadiyah ke Minangkabau. 
Meskipun tidak termasuk ke dalam buku sejarah, tetapi di dalam beberapa tulisannya, Hamka menyisipkan peristiwa-peristiwa sejarah yang terjadi. Seperti buku Tasauf: Perkembangan dan Pemurniannya (1958), Islam dan Adat Minangkabau (1985), dan Antara Fakta dan Khayal "Tuanku Rao" (1974).

\section{KESIMPULAN}

Hamka adalah seorang sejarawan di samping sebagai seorang ulama dan sastrawan. Meskipun pandangan ini masih banyak yang tidak menerima. Ia telah memiliki ketertarikan di bidang sejarah sejak masa kanak-kanak. Keberadaan perpustakaan-perpustakaan di sekitar tempat tinggalnya pada waktu itu menjadikan ia semakin menyenangi sejarah. Hal ini kemudian terealisasi dengan beberapa karyanya di bidang sejarah. Bagi Hamka sejarah adalah sumber informasi dari berbagai kemajuan peradabanperadaban masa lampau. Ia menekankan dalam mempelajari dan menuliskan sejarah, seseorang harus mengembara dan melihat langsung kepada obyek yang diteliti. Pengamatan secara langsung akan memberikan pemahaman yang mendalam, memperoleh penjelasan dan petunjuk, serta pengajaran.

Perspektif ini merepresentasikan dari keseluruhan tahapan metodologi yang harus dilalui oleh seorang peneliti sejarah. Adalah melakukan pengumpulan sumber-sumber primer maupun sekunder, verifikasi dan interpretasi terhadap sumber yang ditemukan hingga pada akhirnya dituangkan ke dalam bentuk tulisan atau historiografi. Hamka termasuk ke dalam kategori sejarawan, disebabkan ia juga memiliki pengalaman sebagai dosen pengampu mata kuliah kajian ini. Meski demikian, latar belakang pendidikan formal Hamka yang terbilang sangat minim menjadikan ia tidak termasuk ke dalam sejarawan profesional, melainkan seorang sejarawan masyarakat.

\section{DAFTAR PUSTAKA}

Agusta, Leon. "Di Akhir Pementasan Yang Rampung." In Hamka Di Mata Hati Umat. Jakarta: Pustaka Sinar Harapan, 1996.

Aljuneid, Khairudin. "In Defense of Guided Reason: Hamka and The Reconstruction of Southeast Asian Islam." History Religion 1, no. 1 (2017): 107-28.

Aljunied, Khairudin. "Reorienting Sufism: Hamka and Islamic Mysticism in the Malay World." Indonesia 101, no. 1 (2016): 67-84. https://doi.org/10.1353/ind.2016.0012.

Azra, Azyumardi. Surau: Pendidikan Islam Tradisionalis Dalam Transisi Dan Modernisasi. Jakarta: Kencana, 2017.

- The Origins Of Islamic Reformism In Southeast Asia. Honolulu: Allen \& Unwin and University of Hawai'i Press, 2004.

Basri. Metodologi Penelitian Sejarab: Pendektan, Teori Dan Praktik. Jakarta: Restu Agung, 2006.

Djamal, Murni. Dr. H. Abdul Karim Amrullah: Pengarubnya Dalam Gerakan Pembaruan Islam Di Minangkabau Pada Awal Abad Ke-20. Jakarta: INIS, 2002.

Esposito, John L. Ensiklopedi Oxford: Dunia Islam Modern. 2nd ed. Bandung: Mizan, 2001.

Hakim, Idrus. Rangkaian Mustika Adat Basandi Syarak Minangkabau. Bandung: Rosdakarya, 1994.

Hamka. Ayabku: Riwayat Hidup DR. Haji Karim Amrullah Dan Perjuangan Kaum Agama Di Sumatera. Jakarta: Umminda, 1982.

- Kenang-Kenangan Hidup. 1st ed. Jakarta: Bulan Bintang, 1974.

- Pandangan Hidup Muslim. Jakarta: Bulan Bintang, 1992.

. Prinsip Dan Kebijakan Dakwah Islam. Jakarta: Pustaka Panjimas, 1984.

- Sejarah Umat Islam. 1st ed. Jakarta: Bulan Bintang, 1975.

- Sejarah Umat Islam. 4th ed. Jakarta: Bulan Bintang, 1976.

- Tafsir Al-Ažbar. 4th ed. Jakarta: Pustaka Panjimas, 1984.

Hamka, Irfan. Ayah.... Jakarta: Republika, 2017.

Jambak, Fabian Fadhly. "Filsafat Sejarah Hamka: Refleksi Islam Dalam Perjalanan Sejarah." Jurnal THEOLOGLA 28, no. 2 (February 20, 2018): $255-72$. https://doi.org/10.21580/teo.2017.28.2.187 7. 
Kartodirdjo, Sartono. Pendekatan Ilmu Sosial Dalam Metodologi Seiarah. Jakarta: Gramedia Pustaka Utama, 1992.

Kuntowijoyo. Pengantar Ilmu Sejarah. Yogyakarta: Tiara Wacana, 2013.

Nizar, Samsul. Memperbincangkan Dinamika Intelektual Dan Pemikiran Hamka Tentang Pendidikan Islam. Jakarta: Kencana, 2008.

Poeradisastra. "Dalam Karya Sastra Pun Berdakwah Dan Bekhorbah." In Hamka Di Mata Hati Umat. Jakarta: Pustaka Sinar Harapan, 1996.

Putra, Apria. "Ulama Dan Karya Tulis: Diskursus KeIslaman Di Minangkabau Awal Abad 20.” Fuaduna: Jurnal Kajian Keagamaan Dan Kemasyarakatan 1, no. 2 (2017): 134-47. https://doi.org/http://dx.doi.org/10.30983 /fuaduna.v1i2.434.

Ramly, Najmuddin, and Hery Sucipto. Ensiklopedi Tokoh Mubammadiyah. Jakarta: Best Media Utama, 2010.

Rush, James R. Adicerita Hamka: Visi Islam Sang Penulis Besar Untuk Indonesia Modern. Jakarta: Gramedia Pustaka Utama, 2017.

Rusydi. Pribadi Dan Martabat Buya Prof. DR. Hamka. Jakarta: Pustaka Panjimas, 1983.

Sirry, Mun'im. Kemunculan Islam Dalam Kesarjanaan Revisionis. Yogyakarta: Suka Press, 2017.

Soedjatmoko, ed. Historiografi Indonesia: Sebuah Pengantar. Jakarta: Gramedia Pustaka Utama, 1995.

\section{Diskusi Ilmiah:}

Ma'arif, Syafi'i. Yunahar Ilyas, dan Nasir Tamara. "Biografi dan Cara Berfikir Hamka." Disampaikan dalam Bedah Buku Adicerita Hamka di Islamic Centre, Masjid Universitas Ahmad Dahlan pada tanggal 28 Desember 2017. 